\title{
Government-Opposition Dynamics in Spain under the Pressure of Economic Collapse and the Debt Crisis
}

\author{
ANNA M. PALAU*, LUZ MUÑOZ MÁRQUEZ and \\ LAURA CHAQUÉS-BONAFONT
}

Government-opposition relations in Spain have been long characterised by a high level of consensus and cooperation. The question analysed here is whether the economic crisis initiated in 2008 has created unprecedented levels of conflict in the political system or whether opposition parties have maintained a cooperative strategy oriented to influence far-reaching policy decisions. Results illustrate that patterns of consensus have decreased significantly since the outbreak of the crisis, and this is partly explained by the rising amount of legislation with socio-economic content, variations in the government's popularity, and the type of government. The analysis also shows that the crisis has increased the incentives of opposition parliamentary groups to oppose European Union legislation, especially among left parties.

Keywords: parliamentary opposition; government type; government popularity; economic crisis; Spain.

\section{Introduction}

Following the outbreak of the world financial crisis in 2008, the economic situation in Spain changed dramatically. The economy, which until that time had been enjoying moderate economic growth and government surplus, was plunged into a deep economic recession, with rising levels of unemployment and increasing public debt. In the wake of the recession and collapse of the country's housing market, José Luís Rodríguez Zapatero's socialist government implemented severe austerity measures aimed at reducing state spending and limiting the public sector deficit. Cutbacks in social welfare programmes, pension and labour market reforms were implemented so the government failed to fulfil an important part of its electoral promises. After the socialist electoral defeat in 2011, Mariano Rajoy's conservative government continued to implement policies to curb spending and to control the state deficit. The conservatives launched a major reform of the labour market and financial system and raised taxes, contradicting some of their ideological principles and electoral commitments. In adhering to the recommendations of the EU and other international institutions and by adopting these austerity plans, both governments assumed high political risks in terms of re-election. Indeed, the measures implemented have given rise to

The Journal of Legislative Studies, 2014

http://dx.doi.org/10.1080/13572334.2014.939565

(C) 2014 Taylor \& Francis 
considerable political controversy and social mobilisation in Spain, and to unprecedented levels of criticism directed towards European institutions.

The question analysed here is the extent to which the economic crisis has transformed government-opposition relations in Spain. As in other advanced democracies, such as Italy (Cazzola, 1974; Di Palma, 1977), the UK (Rose, 1980), the US (Adler \& Wilkerson, 2013; Rose, 1984) and Germany (Rose, 1984; Saalfeld, 1990), government-opposition relations in Spain are characterised by a high level of consensus and cooperation (Capo, 1994; Mújica \& Sánchez Cuenca, 2006). Yet to what extent has this consociational behaviour been affected by changes to the social, political and economic context? Is government-opposition consensus immune to the economic crisis? Or, on the contrary, does the crisis represent an opportunity for opposition parties to undermine the government's position, creating unprecedented levels of conflict in the political system? To answer these questions, the patterns of consensus in the Spanish parliament between 2001 and 2012 are examined, considering as explanatory variables the type of government (minority or majority), the socio-economic content of legislation, fluctuations in the government's popularity, and the extent to which the legislative measures are defined by EU institutions. The analysis is based on the final voting pattern for all organic laws and the validation votes for all decree-laws passed in the Spanish parliament during this period.

The following section introduces the theoretical framework and the hypotheses to be tested. The third section outlines the data and methodology used in the analysis. The fourth section describes the changes in government-opposition dynamics in Spain between 2001 and 2012. The fifth explains which variables account for these changes and the last part summarises the main conclusions to be drawn from the analysis.

\section{Theoretical Framework and Hypotheses}

Opposition behaviour is central to an understanding of the dynamics of representative democracies. Voting for or against policy decisions is informative about partisan controversy and dissent, providing relevant information about the functioning of democracy (Dahl, 1966; Hix, 2013). Despite this, most studies have focused their attention on the analysis of the output of the legislative process and the spatial location of political parties on policy issues, tending to neglect the analysis of the opposition as a political actor (Mújica \& Sánchez Cuenca, 2006; Parry, 1997). Scholars now have excellent exogenous measures of spatial location of parties (Benoit \& Laver, 2007; Klingemann, Volkens, Bara, \& Budge, 2006), but these analyses do not explain the extent to which these estimated locations translate into revealed behaviour in the most important arena of representative democracy (Petrocik, 1996; Poole, 2005).

A large set of studies analyses voting behaviour in parliaments by considering political parties' tactical choices based on two contrasting options: conflict or cooperation. The adversarial model suggests that opposition parties adopt a 
distinct position from the party in office following a strategy based on conflict (Rose, 1980). Partisanship is considered the driving force in politics, and opposition groups are supposed to behave tactically, emphasising disagreements and confrontation in order to weaken the incumbent government and to gain office. From this perspective, the more a party and its electorate assign relevance to an issue, the more costly it will be to behave consensually (Cazzola, 1974; De Giorgi, 2011; Green-Pedersen, 2007; Jenkins, 2010; Rose, 1984). Opposition behaviour can be expected to be more in conflict on highly visible, politicised issues affecting basic citizens' rights, such as same-sex marriage or abortion, and on economic and social issues, where parties represent different ideological positions and socio-economic interests. For these issues it is hard to justify any shift from the initial party position in the face of the electorate, which is liable to generate conflict and confrontation that persists over time (Mújica \& Sánchez Cuenca, 2006).

By contrast, the consensual model suggests that parties agree on fundamental issues and that opposition parliamentary groups cooperate with the government to participate in important policy decisions. Parties are in opposition as they are out of government, but they are not necessarily in constant disagreement with the government (Norton, 2008). The parliament is considered a venue for expressing partisan or ideological divisions but it is also an operational governing body oriented to solving problems (Adler \& Wilkerson, 2013). This means that parliamentary representatives do not always view choices in purely partisan terms but choose to cooperate on important issues that must be solved even at the risk of suffering electoral consequences. On issues of national interest affecting the whole electorate, such as defence or terrorism, consensus is expected to be high and a problem-solving perspective more likely (Adler \& Wilkerson, 2013; Rose, 1984).

As Moury and De Giorgi (2014) argue in the Introduction to this comparative work, because of the characteristics of the actual economic crisis, the dilemma between opting for conflict or cooperation has become particularly acute. In line with the consensual model, in a context of severe economic crisis, opposition parties tend to maintain and even strengthen the pattern of cooperative relations with the government in order to influence far-reaching policy decisions on economic and social issues (Adler \& Wilkerson, 2013). By contrast, the adversarial model suggests that in a context of economic crisis voters are more likely to withdraw support from the incumbent government, increasing the opposition's incentive to mobilise popular discontent using a strategy based on conflict (LewisBeck, 1988). That is, the economic crisis provides a unique opportunity for opposition political parties to weaken the incumbent government, increasing their possibility of winning power at the next elections. Accordingly, the first hypothesis can be defined as follows:

H1: If the adversarial model holds true, government-opposition relations in Spain should have become increasingly controversial, especially 
regarding socio-economic issues; by contrast, if the consensual hypothesis holds true, government-opposition relations should have maintained their traditional character based on consensus.

Parliamentary behaviour is shaped, to a large extent, by formal institutions and the type of government (see, for example, Cazzola, 1974; Dahl, 1966; Duverger, 1951; Hix, 2013; Mújica \& Sánchez Cuenca, 2006; Pasquino, 1995; Sartori, 1966). In general, it is expected that governments have fewer incentives to seek agreement with opposition parties when they hold a majority of seats. In Spain, this was the case of the governments of the Partido Popular (PP) from 2000 to 2004 (with José Maria Aznar as president of the government) and from 2011 to the present (under Mariano Rajoy). Consensus becomes more likely with minority governments, mainly because the incumbent needs the support of other parties to pass the budget and legislation. For the period analysed here, this was the case of Zapatero's socialist government (PSOE), ${ }^{1}$ which always governed in a minority (from 2004 to 2011). During the first legislature (20048), the PSOE headed a minority government with the support of the far left (Izquierda Unida [IU] and Iniciativa per Catalunya Verds [ICV]) and Esquerra Republicana de Catalunya (ERC), while after 2008 this formal, stable support was diluted into specific and punctual alliances with left and regional political parties. Accordingly, the second hypothesis can be defined as follows:

\section{H2: During minority governments, consensus is higher than under majority governments.}

In line with Moury and De Giorgi, government-opposition dynamics are strongly related to the government's popularity and the risk of electoral defeat. An extensive body of research has reported that crisis conditions tend to undermine citizens' support for incumbents (Browne, Frendreis, \& Gleiber, 1986; Diamond, Linz, \& Lipset, 1989). The magnitude of the electoral impact is correlated with the depth of the crisis experienced in the pre-electoral period measured in terms of variations in exchange rates, gross domestic product (GDP) and/or inflation (Remmer, 1991). In this context, the incentives for the opposition parties to attack the government and to engage in a more adversarial strategy increase as they set about undermining the already low popularity of the government.

In 2008, following Zapatero's re-election, 21 per cent of citizens considered the government's performance to be 'bad' or 'very bad', while four years later, at the end of the legislature, this percentage had risen to 58 per cent. Similarly, the government's popularity declined constantly after the PP won the 2011 general elections, with 66 per cent of Spanish citizens expressing their disapproval of government reforms in 2013 (CIS Barometer, 2013). These falling levels of government popularity are strongly related to the economic crisis ushered in around 2008, characterised by unprecedented levels of complexity and intensity (Barreiro, 2011; Ortega \& Peñalosa, 2012; Reinhart \& Rogoff, 2009). Unemployment rates have risen more than 15 per cent since the beginning of the crisis, from 9 per 
cent of the workforce in 2007 to 22 per cent in 2011 and 27 per cent in 2013. The Spanish economy entered recession in 2009 , with a 4 per cent negative growth rate, while rising public and private debt levels led to a serious sovereign debt crisis. This poor economic performance and the social consequences of the policy measures adopted to combat the crisis seriously undermined the popularity of incumbent governments. As a result, the third hypothesis can be defined as follows:

H3: Parliamentary consensus falls as the popularity of the incumbent decreases.

Finally, the present economic crisis, in contrast to previous ones, is characterised by the fact that it is being managed in a context of multilevel governance, where most economic policy instruments are in the hands of EU institutions (Hooghe \& Marks, 2001). The delegation of decision-making powers to the EU and the creation of European monetary union have meant that most policy measures implemented to overcome the crisis have been prescribed or recommended by external actors. The reform of the Spanish Constitution to cap budget deficit in 2011, the reform of the pension system in 2011 or the provision of rescue loans to the Spanish banks in 2012 are some examples. Existing research has analysed extensively the importance of the strategic interaction between political parties in an attempt to understand the impact of Europe on domestic policies, considering both the role of EU-sceptical extreme parties (Hooghe \& Marks, 2009; Kriesi et al., 2008) and the incentives for mainstream political parties to politicise EU issues (Green-Pedersen, 2012). It is argued that pro-European mainstream parties are more likely to cooperate with the incumbent government when policies adopted at the domestic level adhere to EU recommendations. By contrast, Eurosceptic parties have few incentives to collaborate with the incumbent government, especially in relation to highly Europeanised issues (Hooghe, Marks, \& Wilson, 2004; Sitter, 2001, 2002; Szczerbiak \& Taggart, 2003).

Party positions on European integration influence the politicisation of EU affairs but formal rules also affect to what extent they are the object of parliamentary debates (Bergman \& Damgaard, 2000; Karlas, 2012; Raunio, 2005; Strøm, Müller, \& Bergman, 2003; Winzen, 2012). In the case of Spain, the parliament plays only a marginal role in relation to EU affairs (it being the executive that intervenes in the agenda-setting and decision-making process) and just a small percentage of directives are finally debated in the Congreso de los Diputados (Palau \& Chaqués-Bonafont, 2012). Moreover, there are no Eurosceptic parties. No political party has questioned Spanish membership of the EU and public opinion has historically been supportive and enthusiastic of Europeanisation (Closa, 1995; Díez Medrano, 2003, 2007; Sánchez, 1999; Szmolka, 1999). Accordingly, the fourth and final hypothesis can be defined as follows:

H4: Government and opposition are more likely to collaborate on EU-related issues than they are on domestic affairs. 


\section{Data and Methodology}

This analysis of government-opposition dynamics draws on a database created by the Spanish Policy Agendas Project ${ }^{2}$ containing information about the final voting patterns for all the organic laws and the validation votes for all the decree-laws passed by the Spanish parliament between 2001 and 2012. A total of 104 organic laws and 169 decree-laws are analysed and coded. The approval of organic laws requires an absolute majority in Congress and they are limited to the regulation of certain issues, these being the exercise of fundamental rights and public liberties, the general electoral system, the approval of regional statutes (Estatutos de Autonomía), and other procedures considered in the Spanish Constitution, including the regulation of the Constitutional Court, the Ombudsman (Defensor del Pueblo) and the states of alert, emergency or siege. Organic laws represent 13 per cent of all the laws passed in Spain in the period 2001-12.

Decree-laws are provisional regulatory acts passed by the executive in case of extraordinary or urgent necessity, or when exceptional circumstances impede the implementation of ordinary legislative procedures. In accordance with the Spanish Constitution, decree-laws cannot affect the regulation of basic state institutions, rights, duties, and liberties of citizens, the Estatutos de Autonomía, or the general electoral system. Decree-laws have to be submitted for debate and voting by the entire Congress within 30 days of their promulgation. The Congress has to adopt a specific decision on their ratification or revocation in the same period, with the option of processing them as executive bills. Decree laws represent 22 per cent of all the laws passed in Spain in the period 2001-12.

The database contains information about the total number of votes and the specific votes cast by each parliamentary group (positive, negative, abstentions and absences). Data about the total number of votes are available on the Spanish Congress webpage (www.congreso.es), while information concerning the voting behaviour of each parliamentary group is available only on request and for the period $2001-12,{ }^{3}$ which is why this analysis was circumscribed to this period. This database draws on those previously created by the Spanish Policy Agendas Project, which provide information about the specific issue addressed by the legislative measure, the legislature, year, month, title, author of the initiative, and the EU content of organic laws and decree-laws (Chaqués-Bonafont, Palau, \& Baumgartner, forthcoming; Chaqués-Bonafont, Palau, \& Muñoz, 2014). Legislation is considered to be Europeanised if it is totally or partially defined by an EU-binding regulatory act (Brouard, Costa, \& Köning, 2011; Palau \& Chaqués-Bonafont, 2012).

The level of conflict and consensus is measured using the index developed by Capo (1994). This index of consensus is based on the following formula:

$$
I C=\frac{v f}{n * v / N}
$$


where $v f$ corresponds to the total number of positive votes cast for a law, $n$ is the number of deputies in the governing party, $v$ is the total number of votes, including positive and negative votes as well as abstentions, and $N$ is the size of the assembly (350). The index can be interpreted as follows: if the index has a value of one, the incumbent party does not obtain support from any other parliamentary group; whereas if the index has a value greater than one, the incumbent obtains support from other groups: the more support it receives, the higher the value.

To analyse the impact of minority-majority governments, in line with Mújica and Sánchez Cuenca (2006), the difference in the number of seats between the incumbent and the main opposition party is taken into account. The analysis of the impact of legislative issue type draws on the 19 topics identified by the Comparative Agendas Project. A dummy, with a value of one if the legislation is related to topic 1 (economy), 3 (health), 5 (labour), 6 (education), 13 (social policy), and 15 (commerce and banking) and zero otherwise, ${ }^{4}$ is used to determine whether socio-economic measures are more open to conflict than other issues. Finally, ${ }^{5}$ government's popularity is measured in accordance with the barometer published by the Centro de Investigaciones Sociológicas (http://www.cis. es) and, more specifically, according to the responses given to the following question: How do you evaluate the government's performance: very good, good, bad, very bad?

\section{Government-Opposition Dynamics in Spain}

Previous analysis of government-opposition dynamics based on the analysis of organic laws (Mújica \& Sánchez Cuenca, 2006) illustrates that consensus has been the dominant pattern in Spanish politics. During the country's first legislature, in the transition to democracy, 97 per cent of organic laws were passed with a positive vote from the main opposition party. This percentage subsequently fell to 44 per cent during Felipe González's first term in office (1982-86), when the socialists enjoyed an absolute majority. It then rose again during the minority governments of Felipe González (1993-96) and José Maria Aznar (19962000), when the percentage reached 76 and 77 per cent, respectively. Overall, between 1979 and 2001, the government and the main opposition party were in agreement on 71 per cent of the organic laws passed in the Spanish parliament.

This pattern was reversed between 2001 and 2012. The consensus declined during José Maria Aznar's majority government (PP), when 61 per cent of organic laws were passed with a positive vote from the main opposition party, but also during Zapatero's first minority government (PSOE), when the percentage fell to 55 per cent. The latter rate can be explained by the controversial policy reforms implemented by the socialists in areas such as education, immigration or the disputed reform to the Catalan Statute introduced during this period. The level of consensus rose again during the socialists' second legislature (to 69 per cent), when although conflict was high in relation to certain issues (for 
example, the reform of the abortion act), a significant number of organic laws concerning issues on which party conflict is very low (for example, the ratification of the Lisbon Treaty) were introduced. By contrast, the level of consensus fell dramatically after 2011, with only 37 per cent of organic laws having been passed with the support of the socialist party, the lowest level of consensus since the transition to democracy. In the case of decree-laws, ${ }^{6}$ the level of consensus rose during Zapatero's first minority government (the percentage of these laws passed with the support of the main opposition party increased from 55 per cent in the period 2001-4 to 64 per cent for the period 2004-8). After 2008 , following the outbreak of the economic crisis, the level of consensus fell to 43 per cent during Zapatero's second legislature and to 28 per cent during that of Rajoy $(2011-12)$.

The index of consensus (Figure 1) and the mean percentage of positive and negative votes (Figure 2) corroborate this decline in parliamentary consensus over time, and especially since 2011, when the PP began to govern with an absolute majority and important reform measures aimed at tackling the economic crisis were passed. If a consideration is given to both organic laws and decree-laws, the results show that the level of consensus was higher during the socialist legislatures - the mean percentage of positive votes increased from 42 per cent during Aznar's absolute majority (2001-4) to 55 and 53 per cent during Zapatero's first and second legislatures, respectively. Consensus, however, declined markedly in 2012, with Rajoy taking office, as the mean percentage of positive votes fell from 53 to 26 per cent, while that of negative votes increased from 12 to 52 per cent.

As Table 1 illustrates, there has also been considerable variation in the voting behaviour of parliamentary groups across legislatures. On the one hand, the two main state-wide political parties - the PSOE and the PP - adopt different

Figure 1: Index of Consensus: Organic Laws and Decree-laws (2001-12)

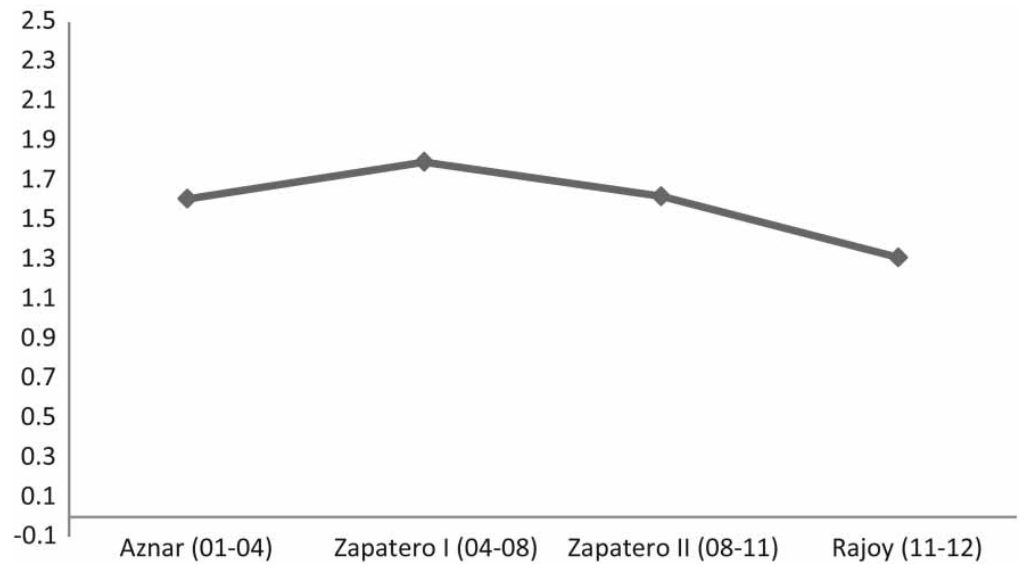


Figure 2: Mean Percentage of Positive and Negatives Votes of Opposition Parliamentary Groups over Time: Organic Laws and Decree-laws (2001-12)

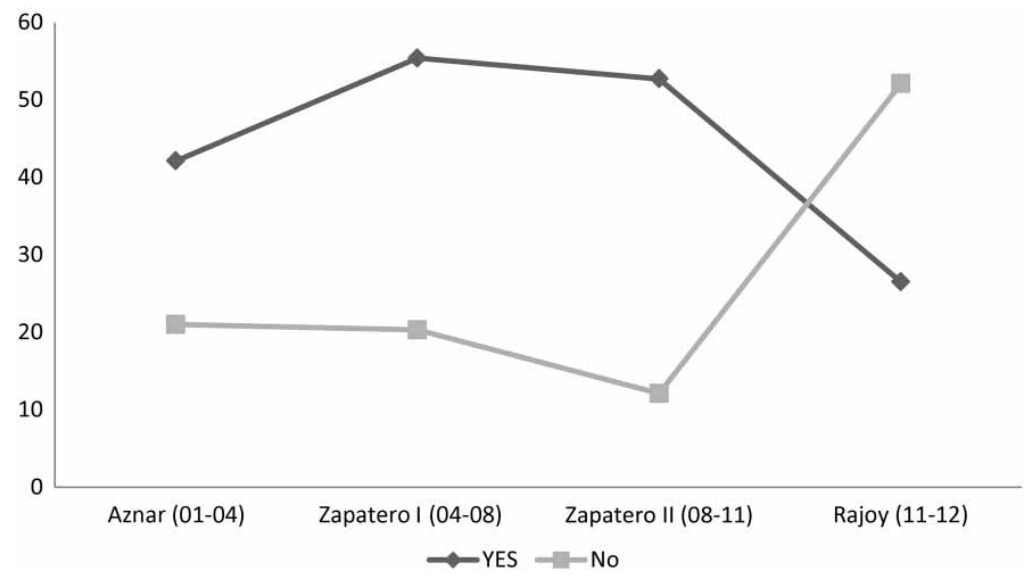

strategies: overall the PP gives more support to the incumbent political party than is the case with the PSOE. The mean percentage of positive votes cast by the PP during the two legislatures governed by the PSOE was 53 per cent. By contrast, the mean percentage of positive votes cast by the PSOE between 2001 and 2004

Table 1: Mean Percentage of Positive and Negative Votes by Different Parliamentary Groups: Organic Laws and Decree-laws (2001-12)

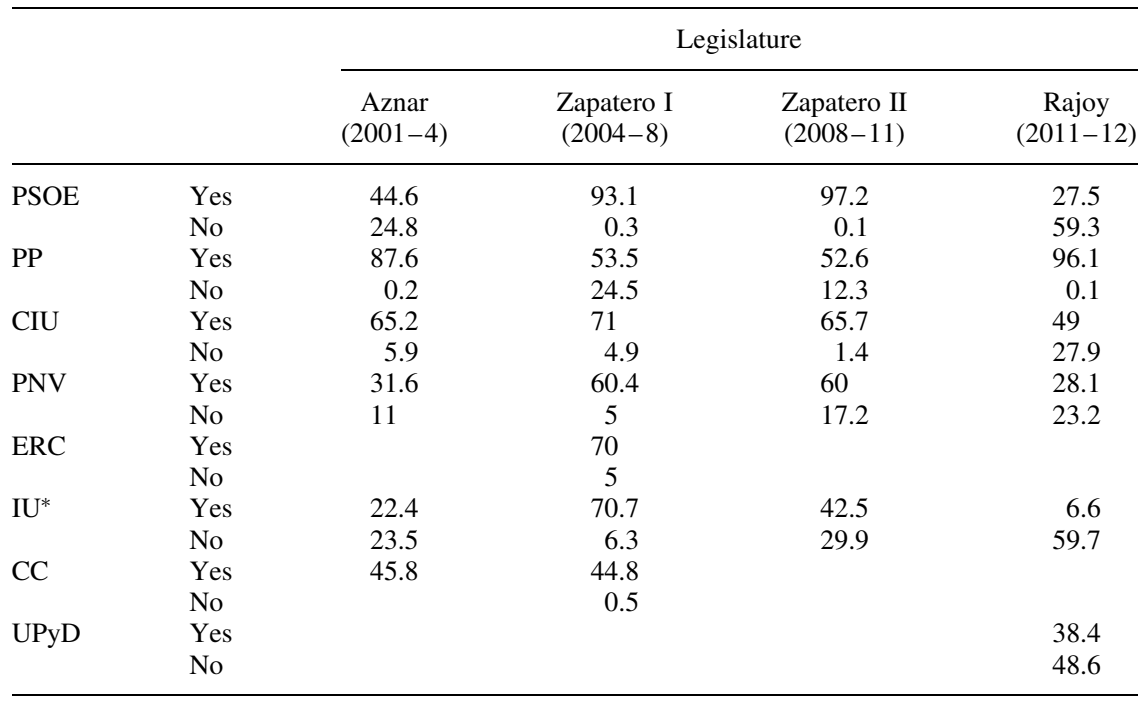

*IU votes with ERC and ICV in the legislature 2008-11 and with ICV and Chunta Aragonesista in 2012. 
(during the Aznar government) was just 45 per cent. The decline in socialist support for the incumbent party was even more marked during 2012, the first year of the Rajoy government, when this percentage fell to 27 per cent. In fact, this pattern is adhered to by all the opposition parties, in particular by the farleft party Izquierda Unida. With a mean percentage of negative votes standing at 60 per cent in 2012, this is the party that most fiercely opposes the PP government, followed by the socialists ( 59 per cent) and UPyD ( 49 per cent). In the case of the regional political parties, their opposition to government policies has also increased in comparison with levels recorded in previous legislatures, albeit less intensively than the opposition expressed by the other parliamentary groups. In the case of CIU, the mean percentage of negative votes increased from 1 per cent in Zapatero's last legislature to 28 per cent in 2012. By contrast, the PNV presented much greater opposition to the legislation introduced by the PSOE, especially in the period 2008-11 (17 per cent). Yet, the mean percentage of negative votes of the PNV increased significantly with Rajoy in power (23 per cent).

\section{Analysis and Results}

To analyse the extent to which changes in the index of consensus can be explained by the type of legislation under debate (that is, the socio-economic content of the proposed measure), the type of government, variations in government's popularity and the degree of Europeanisation (whether the measure involves EU-related legislation), an ordinary least squares regression (OLS) regression was conducted (see the following equation). Differences between the parliamentary groups were analysed using the same regression equation but considering the mean percentage of positive votes cast by each group as the dependent variable. In the case of the PP and the PSOE, the fact of their being in office or in opposition was also taken into consideration.

$$
I C=C+\beta_{1} \text { SocEcolssues }+\beta_{2} \text { SeatDif }+\beta_{3} \text { GovUnpop }+\beta_{4} \text { EUcontent }+\varepsilon
$$

where: $I C=$ Capo's (1994) index of consensus for all organic laws and decreelaws passed between 2001 and 2012; SocEcoIssues = unity if organic laws and decree-laws involve socio-economic issues, zero otherwise; SeatDif $=$ difference in the number of seats between the government and the main party in opposition; GovUnpop = government's unpopularity measured by the percentage of citizens considering the government's performance as being 'bad' or 'very bad'; and EUcontent $=$ unity if organic laws and decree-laws are totally or partially defined by an EU binding regulatory act.

As Figure 3 illustrates, the amount of socio-economic legislation has increased in recent years in parallel with the worsening of the economic crisis. During Aznar's last government (2001-4) and Zapatero's first legislature (2004-8), legislation tackling socio-economic issues accounted for 38 and 35 per cent of the total (considering both organic laws and decree-laws), 
Figure 3: Percentage of Socio-economic Legislation, Unemployment Rate, Variations in the Popularity of the Government and Index of Consensus (2001-12)

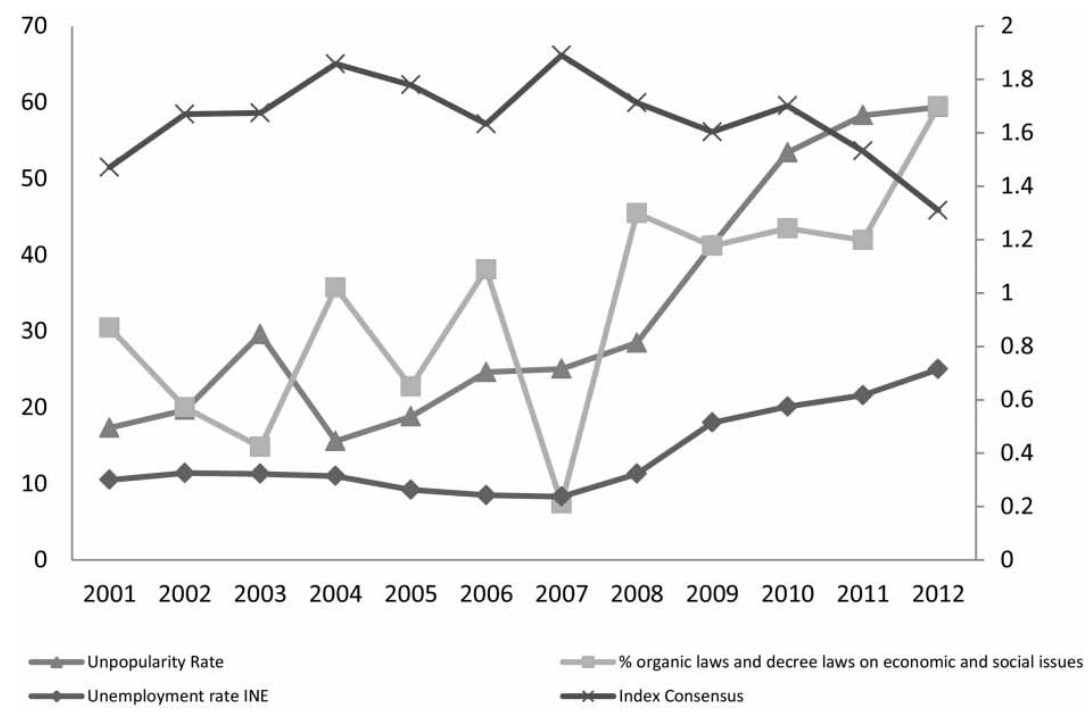

respectively. Between 2008 and 2011, this percentage rose to 45 per cent, and in 2012, under Rajoy, it reached 65 per cent. This increase was especially high in the case of decree-laws, which, since 2008, have accounted for 89 per cent of all socio-economic legislation. The regression results (Table 2) ${ }^{7}$ show that the consensus on socio-economic issues was lower than that on other issues - the index of consensus fell by 0.2 when legislation involved socio-economic measures. This variable is negative and statistically significant for all the opposition groups (Table 3). Only when the PP and the PSOE are in office are they more likely to give support to economic and social measures, because they initiate legislation - 71 per cent of all organic laws and decree-laws were introduced by the government.

Although the index of consensus on economic and social issues declined in Zapatero's second legislature and immediately after the PP took office, conflict has always been higher in relation to socio-economic measures than in relation to that of any other policy area (Figure 4). Moreover, following the outbreak of the crisis, consensus declined in relation to all policy areas, not just in relation to socio-economic measures. Overall, in relation to $H 1$, these results demonstrate that opposition parliamentary groups tend not to opt for a strategy based on cooperation to tackle the crisis, nor do they adopt a problem-solving perspective. On the contrary, conflict concerning socio-economic affairs has always been high and it has increased since the outbreak of the crisis, and at present it is especially marked since the PP won an absolute parliamentary majority at the 2011 general elections. 
Table 2: OLS Regression Results: Variables Affecting the Index of Consensus

\begin{tabular}{lc}
\hline Economic and social issues & $-0.209^{* * *}(0.000)$ \\
Seat differences & $-0.004^{* * *}(0.000)$ \\
Government unpopularity & $-0.004^{* *}(0.006)$ \\
EU content & $-0.046(0.365)$ \\
Constant & 1.996 \\
$R$-Square & 0.168 \\
$N$ & 273 \\
\hline
\end{tabular}

Note: $p<0.10 ;{ }^{*} p<0.05 ;{ }^{* *} p<0.01 ;{ }^{* * *} p<0.001$.

Table 3: OLS Regression Results: Variables Affecting the Decision of Parliamentary Groups to Vote Yes for Legislation (2001-12)

\begin{tabular}{|c|c|c|c|c|c|c|c|}
\hline Group & $\begin{array}{l}\text { Economic and } \\
\text { Social Issues }\end{array}$ & $\begin{array}{c}\text { Seats } \\
\text { Differences }\end{array}$ & $\begin{array}{l}\text { Government } \\
\text { Unpopularity }\end{array}$ & $\begin{array}{c}\text { EU } \\
\text { Content }\end{array}$ & Intercept & $R$-Square & $N$ \\
\hline PSOE & $\begin{array}{l}-8.115^{*} \\
(0.02)\end{array}$ & $\begin{array}{l}-1.154^{* * *} \\
(0.000)\end{array}$ & $\begin{array}{l}0.164^{* * *} \\
(0.000)\end{array}$ & $\begin{array}{c}3.197 \\
(0.329)\end{array}$ & 108.766 & 0.575 & 248 \\
\hline PSOEGov & $\begin{array}{c}0.774 \\
(0.245)\end{array}$ & - & $\begin{array}{l}0.121^{* * *} \\
(0.000)\end{array}$ & $\begin{array}{l}-0.504 \\
(0.424)\end{array}$ & 90.89 & 0.239 & 146 \\
\hline PSOEOpo & $\begin{array}{c}-22.098^{* *} \\
(0.01)\end{array}$ & - & $\begin{array}{l}-0.232 \\
(0.312)\end{array}$ & $\begin{array}{c}7.112 \\
(0.363)\end{array}$ & 51.383 & 0.1 & 102 \\
\hline PP & $\begin{array}{c}-12.969^{* *} \\
(0.006)\end{array}$ & $\begin{array}{l}0.781^{* * *} \\
(0.000)\end{array}$ & $\begin{array}{c}0.006 \\
(0.962)\end{array}$ & $\begin{array}{l}-6.45 \\
(0.142)\end{array}$ & 47.528 & 0.267 & 248 \\
\hline PPGov & $\begin{array}{c}2.281 \\
(0.075)\end{array}$ & - & $\begin{array}{l}0.206^{* * *} \\
(0.000)\end{array}$ & $\begin{array}{l}-0.417 \\
(0.724)\end{array}$ & 82.932 & 0.34 & 102 \\
\hline PPOpo & $\begin{array}{c}-22.543^{* *} \\
(0.004)\end{array}$ & - & $\begin{array}{c}0.048 \\
(0.833)\end{array}$ & $\begin{array}{l}-9.926 \\
(0.179)\end{array}$ & 62.711 & 0.077 & 146 \\
\hline CIU & $\begin{array}{c}-12.828^{* *} \\
(0.008)\end{array}$ & $\begin{array}{l}-0.167^{+} \\
(0.065)\end{array}$ & $\begin{array}{l}-0.244^{+} \\
(0.076)\end{array}$ & $\begin{array}{l}-7.049 \\
(0.121)\end{array}$ & 86.294 & 0.089 & 248 \\
\hline PNV & $\begin{array}{r}-13.84^{* *} \\
(0.014)\end{array}$ & $\begin{array}{l}-0.57^{* * *} \\
(0.000)\end{array}$ & $\begin{array}{c}0.012 \\
(0.939)\end{array}$ & $\begin{array}{c}3.081 \\
(0.561)\end{array}$ & 71.337 & 0.137 & 248 \\
\hline $\mathrm{IU}$ & $\begin{array}{c}-13.375^{* *} \\
(0.004)\end{array}$ & $\begin{array}{l}-0.755^{* * *} \\
(0.000)\end{array}$ & $\begin{array}{l}-0.37^{* *} \\
(0.005)\end{array}$ & $\begin{array}{l}-3.45 \\
(0.421)\end{array}$ & 86.074 & 0.329 & 248 \\
\hline
\end{tabular}

Notes: We have only considered those groups with parliamentary representation during the whole period under analysis (2001-12). For those parties that only have parliamentary group in one legislature, such as ERC or UPyD, it is not possible to control for the impact of some variables in the model, for example the type of government. In the case of IU, the parliamentary group includes ERC and ICV in the legislature 2008-11 and ICV and Chunta Aragonesista in 2012. ${ }^{+} p<0.10 ;{ }^{*} p<0.05 ;{ }^{* *} p<0.01 ;{ }^{* * *} p<0.001$.

The regression results also illustrate that as the difference between the number of seats held by the government and the main opposition party increases, the index of consensus decreases. As Table 3 illustrates, this variable is statistically significant and the coefficient negative for all parliamentary groups - as the difference in the number of seats increases, the mean percentage of positive votes for legislation falls - with the exception of the PP, which presents a positive coefficient because it always enjoyed an absolute majority during the period of analysis (Figure 5). ${ }^{8}$ In the case of IU, support was higher in Zapatero's first legislature 
Figure 4: Index of Consensus (2001-12): Differences by Type of Legislation

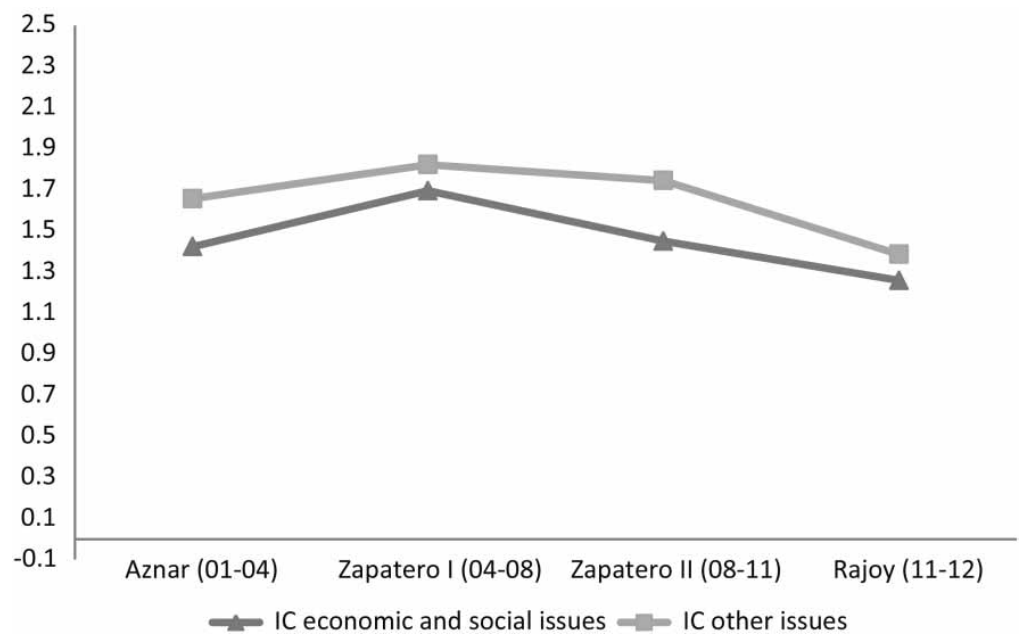

as the socialists relied on the support of this party, as well as that of ERC, to govern. Following the electoral reverse suffered by IU in the 2008 general elections, the mean percentage of positive votes of this group fell, initiating a period of greater opposition to government legislation. Overall, these results corroborate

Figure 5: Mean Percentage of Positive Votes for Legislation Considering Seats Difference and Parliamentary Groups

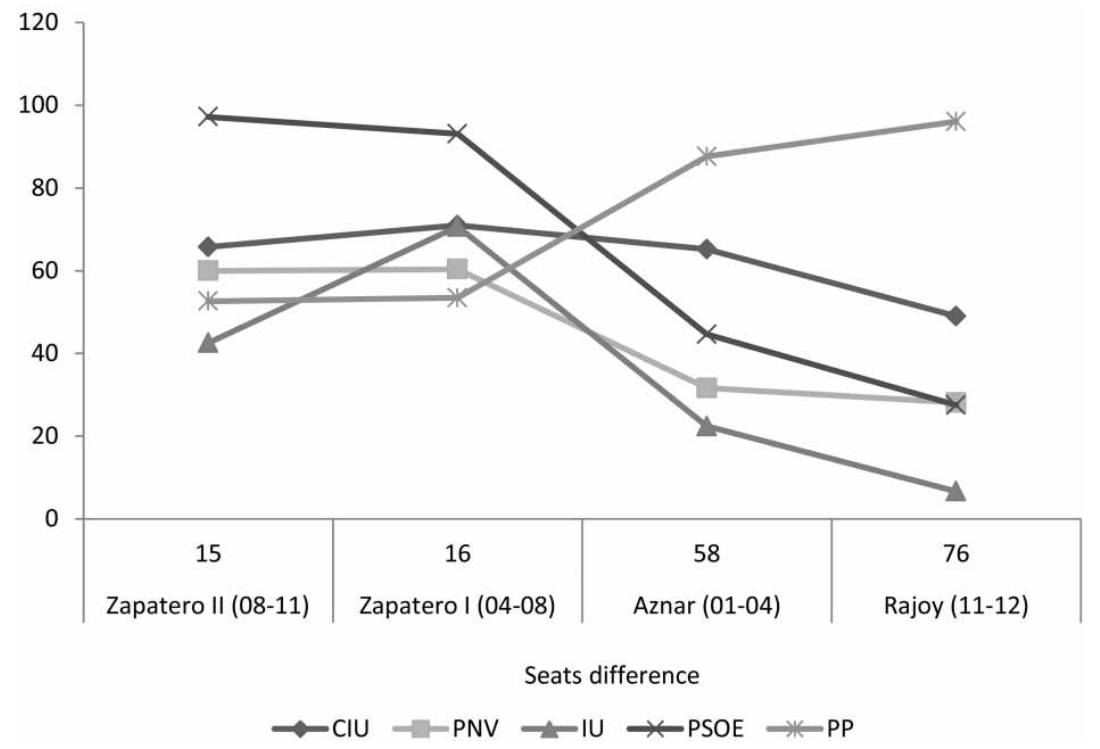


H2: the type of government significantly affects the pattern of consensus in the Spanish parliament.

Changes in the popularity of the government also seem to affect the pattern of consensus: as the percentage of the public that believes the government to be doing a 'bad' or 'very bad' job increases, the index of consensus falls. Given that the likelihood of winning office is especially high in the case of the two state-wide parties (the PP and the PSOE), it is particularly interesting to analyse how changes in the popularity of the incumbent affect the voting behaviour of these two parties that have alternated in power over the last few decades in Spain. The results show that as the popularity of the PP government falls, the PSOE is less likely to give support to the incumbent government (a statistically significant negative coefficient). This accounts for the high percentage of negative votes cast by the PSOE in relation to the legislation introduced by Rajoy, especially regarding socio-economic legislation (Figure 6). By contrast, fluctuations in the popularity of the Aznar government did not significantly affect the voting behaviour of the PSOE in the period 2001-4, basically because the popularity of the conservatives remained high, with the exception of the year 2003, coinciding with citizen discontent with Spain's involvement in the Iraq war (Figure 3).

In the case of the PP, by contrast, the regression results illustrate that when this party is in opposition and the popularity of the PSOE is low, it is more likely to vote in favour of legislation. But the coefficient is not statistically significant. Moreover, although the positive coefficient could suggest that the PP voting behaviour is designed to overcome the crisis by adopting a strategy of cooperation, if the same regression is run considering only socio-economic legislation, the coefficient becomes negative. As Figures 6 and 7 show, the PP gave

Figure 6: Mean Percentage of Positive Votes, Negative Votes and Abstentions of the PSOE to Socio-economic Legislation

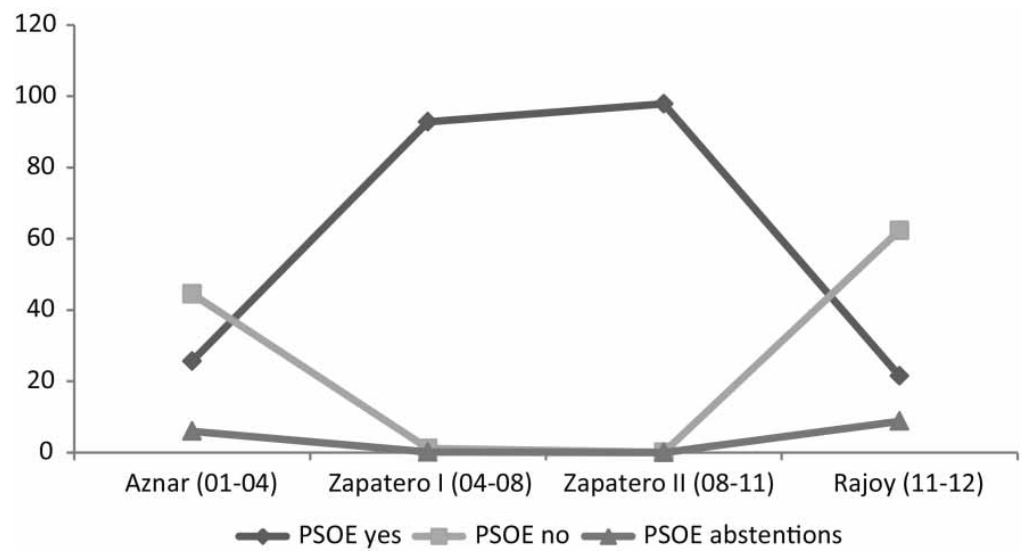


Figure 7: Mean Percentage of Positive Votes, Negative Votes and Abstentions of the PP to Socioeconomic Legislation

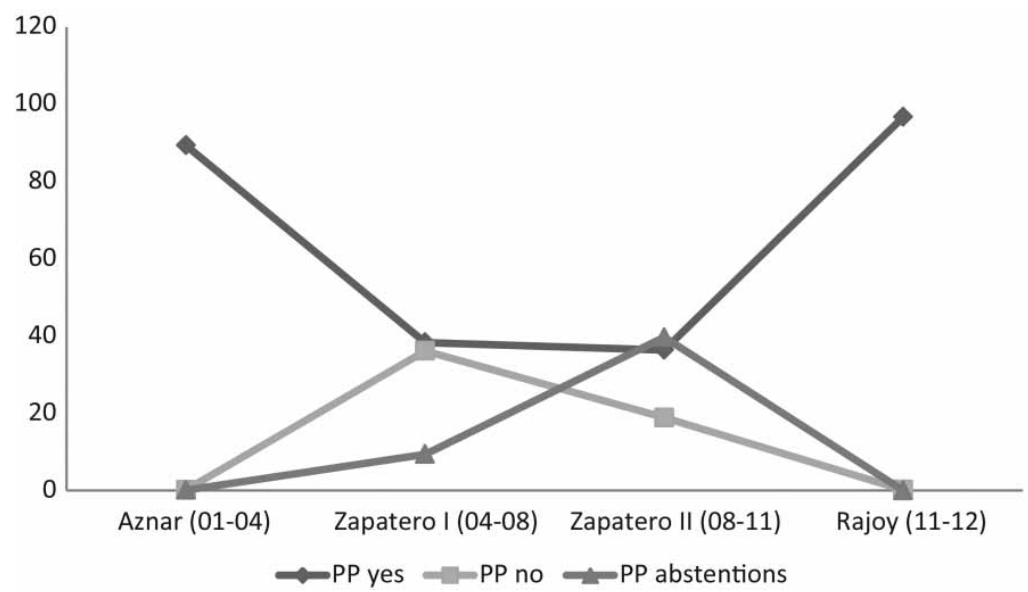

more support to the socio-economic legislation passed by Zapatero designed to tackle the crisis than the PSOE have given to date to the measures adopted by Rajoy, although the PP basically adopted a strategy based on abstention: the mean percentage of PP abstentions in votes on socio-economic legislation increased from 9 per cent during Zapatero's first legislature to 40 per cent in his second term in office. The PP gave support to some of the measures introduced by the PSOE to tackle the crisis, for example legislation designed to facilitate credit access for businesses and families, but in other important areas of policymaking, such as the labour market reform of 2010 or the package of economic measures introduced in 2008 to promote economic activity, the PP abstained.

A possible interpretation of this abstention is that the conservative party did not want to give support to the measures passed by the socialists but neither did they want to appear to be in disagreement with EU institutions, given that the majority of these policies were introduced in line with EU recommendations. The PP strategy therefore was that of not taking a public stance so as to maximise utility in the eyes of voters and EU institutions, given the likelihood of their winning office in the next elections. ${ }^{9}$ The analysis of PP abstentions shows that during Zapatero's second legislature the abstention rate was higher on EUrelated legislation (42 per cent) than it was on domestic measures (36 per cent). As for the other parliamentary groups, CIU and IU present a regression coefficient that is negative and statistically significant, indicating that they behave less consensually when the unpopularity of the incumbent government is high, this being especially true of IU. As for the PNV, the coefficient is not statistically significant because of the high percentage of abstentions recorded by this group in votes concerning policies adopted by the Rajoy government. 
In the case of EU-related measures, the results show that the index of consensus declines when legislation is of this nature; and while the coefficient is not statistically significant, its negative sign suggests that the economic crisis may have reduced the incentives for Spanish parliamentary groups to cooperate on EUrelated affairs. It might be the case that the crisis has undermined the outputbased legitimacy that has historically explained the support from public opinion and the political parties in Spain for European integration. As Jones (2009) argues, the crisis has sapped support for the euro, undermined trust in EU institutions, especially the European Central Bank, and in so doing, it has also exposed a weakness in the output-oriented legitimacy of the EU. In this sense the crisis would appear to have significantly affected one of the pillars that has traditionally upheld support for European integration in Spain: economic growth and a reduction of the difference in living standards between Spain and the rest of Europe (Díez Medrano, 2007).

As a result, some political parties, especially those to the left (for example, the IU), which were already critical of the social consequences of the Maastricht Treaty and the Constitutional Treaty, have started to express serious concerns about the turn of events in specific EU policy areas. As Figure 8 illustrates, IU is the parliamentary group that expresses greatest opposition to EU-related legislation, especially to measures tackling socio-economic issues. Other parties similarly oppose EU-related legislation, but they adopt different strategies over time. When the PP and the PSOE are in power, these two parties never oppose EUrelated socio-economic legislation. However, when they are in opposition, they adopt a completely distinct voting behaviour. In the case of the PSOE, during the Rajoy government the mean percentage of negative votes increased to 55

Figure 8: Mean Percentage of Negative Votes to Legislation With and Without EU Content by Political Party (2001-12)

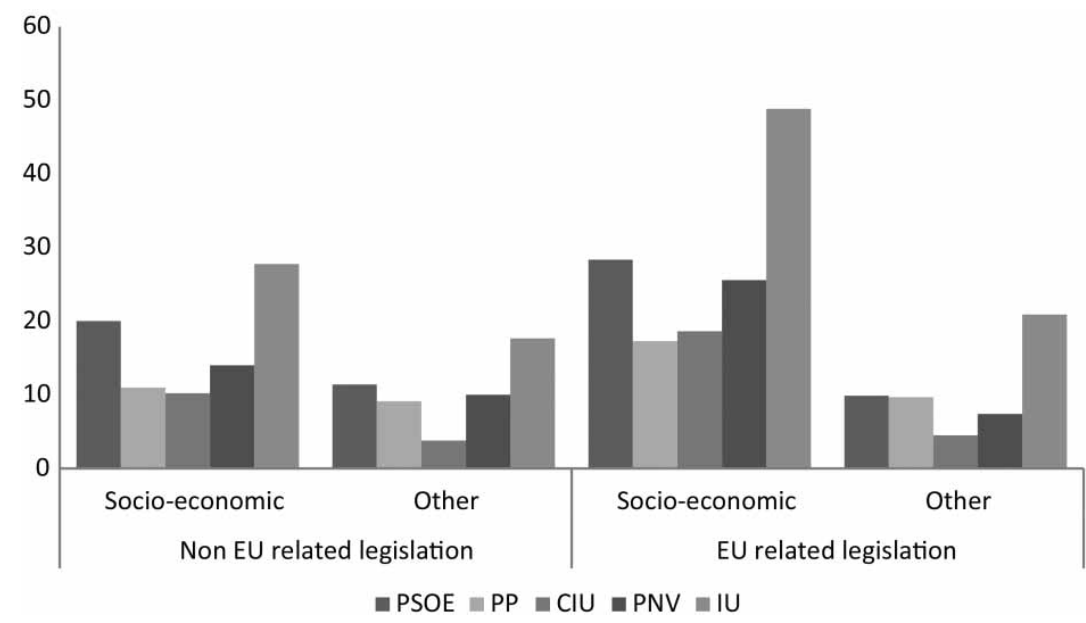


per cent. In the case of the PP, on the other hand, when in opposition, and especially during Zapatero's last legislature, the party opposition to EU-related legislation was lower ( 27 per cent of negative votes) and, as outlined above, adopted a strategy based primarily on abstention. In the case of IU, its opposition to this type of legislation has always been high, presenting a mean percentage of negative votes that has consistently been above 50 per cent during both Zapatero's last legislature and the first two years of the Rajoy government.

Overall, and as a direct result of the economic crisis, Spanish parties, and especially those to the left, have not called into question Spanish membership of the EU, but they now have additional incentives to pay attention to EU affairs as a means of demonstrating their disagreement with EU decisions and also of responding to shifting public opinion perceptions of European integration. According to a recent poll, Spanish citizens are increasingly distancing themselves from national institutions and at the same time becoming more critical of EU institutions. A large majority of Spaniards (86 per cent) think that if EU institutions continue to implement the policies that have been developed to manage the crisis, the EU will no longer be 'useful'. Moreover, 84 per cent believe that the EU's economic policies respond more to German interests than they do to those of other countries, and 94 per cent consider it necessary to reform EU institutions (CIS Barometer, 2013).

\section{Conclusions}

The economic crisis has contributed significantly to the reduction in the level of consensus between government and opposition in Spain. Indeed, the consensus index has fallen since the outbreak of the crisis during Zapatero's second legislature (2008-11), and the level is now particularly low under Mariano Rajoy's government (2011-12). This dynamic is partly explained by the rising amount of legislation with socio-economic content introduced to tackle the crisis; however, the type of government should also be taken into account to understand patterns of conflict and cooperation. The results reported here illustrate that consensus increases when the incumbent is in need of the support of opposition parties to pass legislation. Opposition support for legislation was higher during the minority governments of Zapatero than it was during the absolute majority enjoyed by Aznar, and is now especially low following the absolute majority won by Rajoy.

The opposition's voting behaviour has also been more adversarial following the outbreak of the crisis because the measures adopted to tackle it have resulted in a marked decline in the popularity of the incumbents. The results illustrate that as the popularity of the government falls the opposition tends to behave less consensually because the possibilities of winning office or improving electoral performance increase. Overall, it seems that the opposition opts for a strategy based on conflict so as to weaken the government rather than for a strategy based on cooperation. The rise in the mean percentage of negative votes in all 
parliamentary groups during the Rajoy legislature or the strategic use of abstention by the PP during Zapatero's last legislature serves to corroborate that problem-solving strategies do not drive politics under the pressure of economic collapse and debt crisis.

Finally, the results illustrate that government-opposition dynamics are influenced by the context of multilevel governance in which many decisions to manage the crisis are taken. Although there are no Eurosceptic parties in Spain's political system, opposition to legislation with EU content has been high during the period of analysis, especially in relation to socio-economic measures and among parties to the left. Economic decline has increased the incentives of opposition parliamentary groups to oppose EU-related legislation as an indication of their disagreement with EU decisions but also to respond to shifting public opinion perceptions of European integration.

\section{Note on Authors}

Anna M. Palau* is a Postdoctoral Researcher in the Department of Constitutional Law and Political Science at the University of Barcelona, Spain, email: apalau@ub.edu; Luz Muñoz Márquez is Researcher and Assistant Professor of Political Science at the University of Barcelona, Spain, email: luzmunozma@ub.edu; Laura Chaqués-Bonafont is Professor of Political Science at the University of Barcelona and Research Fellow at the Institut Barcelona d'Estudis Internacionals, Spain, email: laurachaques@ub.edu

*Corresponding author

\section{Acknowledgements}

This research was undertaken by the Grup d'Anàlisi Comparada de l'Agenda Política (Spanish Policy Agendas Project) with the institutional support of the AGAUR and the Ministerio de Economía y Competitividad.

\section{Funding}

This work was supported by Agència de Gestió d'Ajuts Universitaris i de Recerca (AGAUR) [grant number SGR 536]; Ministerio de Economía y Competitividad [grant number CSO-2012-31214].

\section{Notes}

1. Full names of all abbreviated parties in the text are the following: PSOE, Partido Socialista Obrero Español; PP, Partido Popular; CIU, Convergència i Unió; PNV, Partido Nacionalista Vasco; ERC, Esquerra Republicana de Catalunya; IU, Izquierda Unida; CC, Coalición Canaria; UPyD, Unión Progreso y Democracia.

2. The legislative databases created by the Spanish Policy Agendas Project have been coded manually by two coders in accordance with the methodology applied by the Comparative Agendas Project, which identifies 19 major legislative fields and 247 subcategories (Chaqués-Bonafont, Palau, \& Baumgartner, forthcoming). 
3. Information about the total number of votes cast (positive, negative, absences and abstentions) is provided for all the decree-laws and organic laws. However, information about the voting behaviour of each parliamentary group is missing in the case of 15 decree-laws and eight organic laws.

4. Subcategory 1523 (natural disasters and accidents) is not considered in topic 15 as it is not directly related to economic and social issues.

5. Although the impact of the economic and fiscal crises is analysed here, the regression model does not specifically include a variable to operationalise the variable 'crisis' by considering, for example, unemployment rates or changes in GDP, because this variable was found to be highly correlated with government popularity and therefore introduced serious multicollinearity into the model.

6. No previous analysis of consensus has been undertaken for decree-laws. Mújica and Sánchez Cuenca (2006) considered only organic laws and so it is not possible to compare these results with the situation prior to 2001.

7. The Durbin-Watson test indicates that there is no autocorrelation, the variance inflation factor (VIF) and tolerance test that there is no multicollinearity and the Breusch-Pagan/Cook-Weisberg test that there is no heteroskedasticity in the regression models.

8. The regression equations that consider the differences between the PP and the PSOE when in office and when in opposition do not take into account the difference in the number of seats. In the case of the PP, this is because when the PP was in opposition the PSOE was always a minority government and the PP always governed with an absolute majority; in the case of the PSOE, this is because this variable is highly correlated with the variable measuring changes in the popularity of government, which introduces a serious multicollinearity problem in the regression.

9. Unlike other countries, such as Norway, Spanish parliamentary rules do not allow representatives to vote either in favour or against legislation (Rasch, 1995). However, there is no single way of interpreting the meaning of such an abstention. For example, its effects are strongly related to the type of government. When the governing party has an absolute majority, abstention cannot prevent the adoption of legislation, but when there is a minority government, abstention may mean that the governing party does not satisfy the quorum required to pass legislation and, therefore, depending on the position taken by other parliamentary groups, it may have a veto effect.

\section{References}

Adler, S., \& Wilkerson, J. D. (2013). Congress and the politics of problem solving. Cambridge: Cambridge University Press.

Barreiro, B. (2011). In the whirlwind of the economic crisis: Local and regional elections in Spain. South European Society and Politics, 17(2), 281-294.

Benoit, K., \& Laver, M. (2007). Estimating party positions: Comparing expert surveys and hand coded content analysis. Electoral Studies, 26, 90-107.

Bergman, T., \& Damgaard, E. (Eds.). (2000). Delegation and accountability in European integration: The Nordic parliamentary democracies and the European Union. Special issue of the Journal of Legislative Studies, 6(1).

Brouard, S., Costa, O., \& Köning, T. (2011). The Europeanization of domestic legislatures: The empirical implications of the Delors' Myth in nine countries. Studies in Public Choice. New York, NY: Springer.

Brown, E., Frendreis, J., \& Gleiber, D. (1986). The process of cabinet dissolution: An exponential model of duration and stability in western democracies. American Journal of Political Science, $30,628-650$.

Capo, J. (1994). Oposición y minorías en las legislaturas socialistas. Revista Española de Investigaciones Sociológicas, 66, 91-113.

Cazzola, F. (1974). Governo e opposizione nel parlamento italiano. Milan: A. Giuffrè.

Chaqués-Bonafont, L., Palau, A., \& Baumgartner, F. (forthcoming). Agenda dynamics in Spain. London: Palgrave.

Chaqués-Bonafont, L., Palau, A., \& Muñoz, L. (2014). Policy promises and governmental activities in Spain. In C. Green-Pedersen \& S. Walgrave (Eds.). Tracing political attention: A novel approach to comparative politics (pp. 183-200). Chicago, IL: Chicago University Press.

CIS Barometer (2013). http://www.cis.es/cis/opencm/ES/1_encuestas/estudios/ver.jsp?estudio= 14010 
Closa, C. (1995). Spain: The Cortes and the EU - a growing together. The Journal of Legislative Studies, 1(3), 136-150.

Dahl, R. (Ed.). (1966). Political oppositions in western democracies. New Haven, CT: Yale University Press.

De Giorgi, E. (2011). L'opposition parlementaire en Italie et au Royaume Uni: Systémique ou axée sur les enjeux? Revue Internationale de Politique Comparée, 18(2), 93-113.

Diamond, L., Linz, J., \& Lipset, S. M. (Eds.). (1989). Democracy in developing countries: Latin America. London: Adamantine Press.

Díez Medrano, J. (2003). Framing Europe: Attitudes to European integration in Germany, Spain, and the United Kingdom. Princeton, NJ: Princeton University Press.

Díez Medrano, J. (2007). La opinion pública española y la integración europea. In F. Morata \& G. Mateo (Eds.), España en Europa - Europa en España (1986-2006) (pp. 205-233). Barcelona: Fundació CIDOB.

Di Palma, G. (1977). Surviving without governing. Berkeley: California University Press.

Duverger, M. (1951). Political parties: Their organization and activity in the modern state. Paris: Armand Colin.

Green-Pedersen, C. (2007). The growing importance of issue competition: The changing nature of party competition in western Europe. Political Studies, 55(4), 608-628.

Green-Pedersen, C. (2012). A giant fast asleep? Party incentives and the politicisation of European integration. Political Studies, 60, 115-130.

Hix, S. (2013). Government-opposition or left-right? The institutional determinants of voting in legislatures (Working Paper). London: London School of Economics.

Hooghe, L., \& Marks, G. (2001). Multi-level governance and European integration. Oxford: Rowman \& Littlefield.

Hooghe, L., \& Marks, G. (2009). Postfunctionalist theory of European integration: From permissive consensus to constraining dissensus. British Journal of Political Science, 39(1), 1-23.

Hooghe, L., Marks, G., \& Wilson, C. (2004). Does left/right structure party positions on European integration? In G. Marks \& M. Steenbergen (Eds.), European integration and political conflict (pp. 120-140). Cambridge: Cambridge University Press.

Jenkins, S. (2010). Examining the influence over roll call voting in multiple issue areas: A comparative US state analysis. Journal of Legislative Studies, 16(1), 14-31.

Jones, E. (2009). Output legitimacy and the global financial crisis: Perceptions matter. Journal of Common Market Studies, 47, 1085-1105.

Karlas, J. (2012). National parliamentary control of EU affairs: Institutional design after enlargement. West European Politics, 35(5), 1095-1113.

Klingemann, H., Volkens, A., Bara, J., \& Budge, I. (2006). Mapping policy preferences II: Estimates for parties, elector and governments in central and eastern Europe, European Union and OECD 1990-2003. Oxford: Oxford University Press.

Kriesi, H., Grande, E., Lachat, R., Dolezal, M., Bornschier, S., \& Frey, T. (2008). West European politics in the age of globalization. Cambridge: Cambridge University Press.

Lewis-Beck, M. S. (1988). Economics and elections: The major western democracies. Ann Arbor: University of Michigan Press.

Moury, C., \& De Giorgi, Elisabetta (2014). Introduction: Conflict and consensus in Parliament during the economic crisis. Journal of Legislative Studies, DOI:10.1080/13572334.2014.939564.

Mújica, A., \& Sánchez Cuenca, I. (2006). Consensus and parliamentary opposition: The case of Spain. Government and Opposition, 41(1), 86-108.

Norton, P. (2008). Making sense of opposition. The Journal of Legislative Studies, 14(1-2), 236-250.

Ortega, E., \& Peñalosa, J. (2012). The Spanish economic crisis: Key factors and growth challenges in the Euro area. Documentos Ocasiones, 1304. Banco de España.

Palau, A. M., \& Chaqués-Bonafont, L. (2012). Europeanization of legislative activity in Spain. In S. Brouard, O. Costa, \& T. Köning (Eds.), The Europeanization of domestic legislatures. The empirical implications of the Delors' Myth in nine countries (pp. 173-196). Studies in Public Choice. New York, NY: Springer.

Parry, G. (1997). Opposition questions. Government and Opposition, 32(4), 451-461.

Pasquino, G. (1995). L'opposizione. Bari: Laterza.

Petrocik, J. R. (1996). Issue ownership in presidential elections, with a 1980 case study. American Journal of Political Science, 40(3), 825-850.

Poole, K. T. (2005). Spatial models of parliamentary voting. Cambridge: Cambridge University Press. 
Rasch, E. (1995). Parliamentary voting procedures. In H. Döring (Ed.), Parliaments and majority rule in western Europe (pp. 488-527). New York, NY: St. Martin's Press.

Raunio, T. (2005). Holding governments accountable in European affairs: Explaining cross-national variation. Journal of Legislative Studies, 11(3-4), 319-342.

Reinhart, C., \& Rogoff, K. S. (2009). The aftermath of financial crises. American Economic Review, 99(2), 466-472.

Remmer, K. (1991). The political impact of economic crisis in Latin America in the 1980s. The American Political Science Review, 85(3), 777-800.

Rose, R. (1980). Do parties make a difference? London: Macmillan.

Rose, R. (1984). Understanding big government. London: Sage.

Saalfeld, T. (1990). The West Bundestag after 40 years: The role of parliament in a party democracy. In P. Norton (Eds.), Parliaments in western Europe. London: Frank Cass.

Sánchez, I. (1999). El déficit democrático en la Unión Europea. In I. Llamazares \& F. Reinares (Eds.), Aspectos políticos y sociales de la integración europea (pp. 94-116). Valencia: Tirant lo Blanch.

Sartori, G. (1966). European political parties: The case of polarized pluralism. In J. LaPalombara \& M. Weiner (Eds.), Political parties and political development (pp. 137-176). Princeton, NJ: Princeton University Press.

Sitter, N. (2001). The politics of opposition and European integration in Scandinavia: Is Euroscepticism a government-opposition dynamic? West European Politics, 24(1), 22-39.

Sitter, N. (2002). Cleavages, party strategy and party system change in Europe east and west. Perspectives on European Politics and Society, 3(3), 425-451.

Strøm, K., Müller, W. C., \& Bergman, T. (Eds.). (2003). Delegation and accountability in parliamentary democracies. Oxford: Oxford University Press.

Szczerbiak, A., \& Taggart, P. (2003, March). Theorising party-based Euroscepticism: Problems of definition, measurement and causality. Paper presented at the European Union Studies Association International Conference, Nashville, TN.

Szmolka, I. (1999). Opiniones y actitudes de los españoles ante el proceso de integración europea. Opiniones y Actitudes, 21. Madrid: CIS.

Winzen, T. (2012). National parliamentary control of European Union affairs: a cross-national and longitudinal comparison. West European Politics, 35(3), 657-672. 